\title{
EGG WHITE CYSTATIN - A REVIEW
}

\author{
KUPAJ Patryk, KORUS Maciej, KORZENIOWSKA Malgorzata*, KOPEC Wieslaw \\ Department of Functional Food Products Development, the Wroclaw University of Environmental \\ and Life Sciences, Wroclaw, Poland.
}

(Received 26 August, Accepted 05 October 2020)

\begin{abstract}
Hen eggs are widely used, not only for human consumption, but also as an important material in food production and in pharmaceutical and cosmetics industry. Cystatin is a biologically active component of egg white, mostly used as an inhibitor of papain-like cysteine proteases. It was isolated from chicken egg white and has later been used in the nomenclature of structurally and functionally related proteins. Cystatins from animals, including mouse, rat, dog, cow and chicken egg white have been isolated and recently used in foodstuffs and drug administration. Cystatin has found its place and use in medicine due to its antimicrobial, antiviral and insecticidal effects, for the prevention of cerebral hemorrhage and control of cancer cell metastasis.
\end{abstract}

Key words: cystatin, egg white, isolation, application, antimicrobial, anticancer

\section{INTRODUCTION}

Chicken egg white cystatin was characterized in the early 80's. Since then, the knowledge of a superfamily of similar proteins present in mammals, birds, fish, insects, plants and some protozoa has expanded and their properties as potent peptidase inhibitors have been firmly established. Today, 11 functional chicken cystatin relatives are known in man. The type 1 cystatins (A and B) are mainly intracellular, type 2 cystatins (C, D, E, F, S, SN, M and SA) extracellular, and type 3 cystatins (L- and H-kininogen) are intravascular proteins [1]. All cystatins inhibit cysteine peptidases of the papain (C1) family and some also inhibit the legumain (C13) family of enzymes [2]. Such proteases play key roles in the intracellular protein degradation (cathepsins B, H, L), are pivotal in the remodeling of bone (cathepsin $\mathrm{K}$ ) and may be instrumental in controlling antigen presentation (cathepsin S, mammalian legumain) [3]. The 3D structures of two of the human cystatins, cystatin $\mathrm{C}$ and $\mathrm{D}$, have recently been determined. These structures together with results from mutagenesis studies shed light on the following: 1) The C1 peptidase binding site, explaining the inhibitory specificities of cystatins; 2) The location and nature of the C13 peptidase binding site; and 3) The

\footnotetext{
*Corresponding author: e-mail: malgorzata.korzeniowska@upwr.edu.pl
} 
mechanism behind the syndrome Hereditary Cystatin C Amyloid Angiopathy, which results when a mutation in the cystatin $\mathrm{C}$ gene causes production of L68Q-cystatin $\mathrm{C}$ and leads to amyloidosis and brain hemorrhage in young adults [4]. There are many examples of biologically active food proteins, with physiological significance beyond the pure nutritional requirements that concern available nitrogen for normal growth and maintenance. Moreover, there are many physiologically active peptides, derived by protease activity from various food protein sources; however, relationships between structural properties and functional activities have not been completely elucidated. Many bioactive peptides have in common structural properties that include a relatively short peptide residue length (e.g. 2-20 amino acids), possessing hydrophobic amino acid residues in addition to proline, lysine or arginine groups [5]. Bioactive peptides are also resistant to the action of digestive peptidases. Antihypertensive peptides, known as Angiotensin I converting enzyme (ACE) inhibitors, have been derived from egg white, milk, corn and fish protein sources [6]. Peptides with opioid activities are derived from wheat gluten or casein, following digestion with pepsin. Exorphins, or opioid peptides derived from food proteins such as wheat and milk (e.g. exogenous sources) have a structure similar to endogenous opioid peptides, with a tyrosine residue located at the amino terminal or bioactive site. Immunomodulatory peptides derived from tryptic hydrolysates of rice and soybean proteins act as to stimulate superoxide anions (reactive oxygen species-ROS), which triggers non-specific immune defense systems. Antioxidant properties that prevent peroxidation of essential fatty acids have also been shown for peptides derived from milk proteins. The addition of a Leu or Pro residue to the $\mathrm{N}$-terminus of a His-His, dipeptide will enhance the antioxidant activity and facilitate further synergy with non-peptide antioxidants (e.g. BHT). Proteins from egg albumen are being researched in the preparation of biological polymer films for use in food packaging. [7].

\section{Cysteine proteinases}

Enzymes constitute a specialized and diverse group of proteins that have several roles in many physiological processes. Proteolytic enzymes such as proteinases which are involved in digestive processes, proenzymes activation, release of physiologically active peptides, complement activation, inflammation processes and others are part of this protein group [8]. Proteinases are grouped into four categories according to the essential amino acid residue at their active sites, the optimum $\mathrm{pH}$ range of activity, amino acid sequences similarities, similarity to inhibitors. Proteinases are classified as Aspartic peptidases (A), Cysteine peptidases (C), Metallopeptidases (M), Serine peptidases (S), Mixed catalytic type (P) and Unknown type (U) [9]. Examples of these have been identified in plants, insects, microorganisms and are all similar to those found in mammals (Table 1).

Inhibitor proteins have been found for each of the four mechanistic classes of proteinases and a large number of proteinases inhibitors are directed towards serineand cysteine proteinases [12]. In contrast, only a few of those inhibitors are known for 
aspartic- and metal-proteinases [13]. Studies on plant protein inhibitors are important due their involvement in defense mechanisms and in the protection of seeds' reserves from premature hydrolysis [14].

Table 1. Groups of proteinases

\begin{tabular}{lccl}
\hline Proteinases & $\begin{array}{c}\text { Amino Acid in } \\
\text { active site }\end{array}$ & $\begin{array}{c}\text { pH optimum } \\
\text { (range) }\end{array}$ & \multicolumn{1}{c}{ Proteins } \\
\hline Serine proteinase & Ser; His & $7-9$ & $\begin{array}{l}\text { Trypsin, Chymotrypsin, Elastase, } \\
\text { Cathepsin(+) G }\end{array}$ \\
Cysteine proteinase & Cys & $4-7$ & $\begin{array}{l}\text { Papain*, Ficin, Bromelain, Ananin, } \\
\text { Cathepsin(+) B, C, H, K, L, O, S and W }\end{array}$ \\
Aspartic proteinase & (2) Asp, Try & Below 5 & Cathepsin(+) D and E, Renin, Pepsin \\
Metallo-proteinase & Metal ion & $7-9$ & Carboxipeptidases A and B, aminopeptidases \\
\hline
\end{tabular}

*Papain isolated from the latex and fruit of Carica papaya have been used to identify cysteine proteinase inhibitor of the plant origin;

$(+)$ The term "Cathepsin" is generally used for the lysosomal cysteine protease $[10,11]$.

\section{Cystatins}

The term cystatin refers to proteins that specifically inhibit the activity of papain and related cysteine proteinases (cathepsin B, H and L, ficin, bromelain). Their presence in microorganisms, animal and plant species may be ubiquitous [15]. These proteins are all related by structure and function to an inhibitor of cysteine proteinase, which was first described in egg white and was later called chicken egg white cystatin [16]. Cystatins have been found to be evolutionarily related, forming the "cystatin superfamily". Members of the superfamily may be divided into three groups (or families) of proteins more closely related which comprise the animal cystatins [17,18] and one family from plant cystatins [19]. The classification in families is based on primary sequence similarities, molecular masses, number of disulfide bonds and subcellular localization. Others families are suggested on the base of these aspects.

\section{Four families of cystatins}

Type 1 cystatins are also called stefins. This type includes cystatin A and B and stefin C. Cystatins of this group do not contain disulfide bridges and carbohydrate residues in their structure. They are also the smallest group of cystatins, with a molecular mass of around $11 \mathrm{kDa}$ Stefins consist of about 100 amino acids and are found in the cytosol [20,21].

Type 2 cystatins are characterized by the presence of two disulfide bridges and some members of this group of cystatins are glycosylated. Their molecular mass is about 13$24 \mathrm{kDa}$. The size of the cystatins in this group is approximately $115 \mathrm{aa}$., the presence of a signal peptide in their structure enables the secretion of these molecules outside the cell. Their relatively high concentration is found in chicken egg white. These types of cystatins are: C, D, S, SN, SA, E, F, and M. [22,23]. 
Type-3 cystatins (kininogens) have been isolated from the plasma and act as thiol protease inhibitors. Kininogens are superior to all other types of cystatins in terms of complexity. Cystatins from this group can be divided depending on their molecular mass as high molecular weight $(88-114 \mathrm{kDa})$ and low molecular weight (50-68 $\mathrm{kDa}$ ) [22]. These proteins are known to have domains in tandem that resulted from two duplications of the genetic material of family-2 cystatins [24]. Kininogens are characterized by glycosylation, the presence of the bradykinin moiety and disulfide bridges. As with type 2, there is also a signal peptide enabling their secretion. The kininogens are a very important factor in blood coagulation [25]. Existing data proved the homology between the sequence of selected type 2 and 3 cystatins and the active site of Bowman-Birk type trypsin inhibitor [26]. There are also cysteine proteinase inhibitors with a similar primary structure to those of the Kunitz-type soybean trypsin inhibitor family [27]. All cystatins have a conserved pentapeptide domain Gln-ValVal-Ala-Gly (especially type1 and 3 cystatins) and homologous sequences (e.g. Gln$\mathrm{X}$-Val-Y-Gly) which is mainly characterized by cysteine proteinase inhibitors in type 2 cystatins $[28,19]$. This pentapeptide and dipeptide regions could be important for the binding to cysteine proteinase [29]. Other conserved sequences are Phe-Ala-Val from the carboxy terminus and also the Phe-Try dipeptide from the amino terminus, which is characterized by type 2 cystatins, but are absent in type 1 and 3 .

Table 2. Major characteristics of mammalian cystatins $[1,36]$

\begin{tabular}{|c|c|c|c|}
\hline Characteristics & Family 1 & Family 2 & Family -3 \\
\hline Amino acid residues & About 100 & $115-120$ & 3 cystatin like domains \\
\hline $\begin{array}{l}\text { Molecular weight } \\
(\mathrm{kDa})\end{array}$ & About 11 & $13-14$ & $\begin{array}{l}\text { High: } 88-114 \\
\text { Low: } 50-68\end{array}$ \\
\hline Disulfide bonds & 0 & 2 & 6 \\
\hline Glycosilated & No & No & Yes \\
\hline Location & Mainly intracellularly & Mainly extracellularly & Intravascularly \\
\hline Cystatins & $\begin{array}{l}\text { Human: A (stefin A), } \\
\text { B (stefin B) } \\
\text { Rat: cystatin } \alpha \text { and } \beta\end{array}$ & $\begin{array}{l}\text { Human: C, D, S, S1, S2, } \\
\text { SN, SA, D } \\
\text { Rat: C, S } \\
\text { Mouse: C } \\
\text { Chicken egg white, } \\
\text { bovine colostrums, ox, } \\
\text { Drosophila. }\end{array}$ & $\begin{array}{l}\text { Human, rat, bovine: } \\
\text { L-kininogen, H-kininogen } \\
\text { Rat: T-kininogen } \\
\text { Ox: kininogen. }\end{array}$ \\
\hline
\end{tabular}

Type 4 cystatins, the phytocystatins [12,19], include almost all plant cysteine proteinase inhibitors [30]. Plant-derived cystatins exhibit features of both type 1 and type 2 . Oryzacystatin, derived from rice grains, was the first to be characterized as the first phytocystatin, which shows a significant resemblance to cystatin in egg white [28]. Plant-derived cysteine inhibitors can be divided into 2 groups: with a single domain, to which most cystatins belong, and multi-domain, which, for example, belongs to 
tomato multicystatin and cystatin of the tomato leaves [19,31-33]. There are studies that report that some phytocystatins exhibit non-competitive papain inhibition kinetics. Such cystatins are corn cystatin I and oryzacystatin-I [34], soybean, L1 and R1 [35], chestnut seed cystatin [31] as shown in Table 2.

\section{Mechanism of interaction between cystatin and cysteine proteinases}

The cystatins are reversible, tight-binding competitive inhibitors of cysteine proteinases $[29,37]$. However, due to their extremely tight interactions with certain target enzymes, reversibility has been difficult to verify and dissociation equilibrium constants are difficult to determine accurately by equilibrium methods [38]. Separate measurements of association and dissociation rate constants have however demonstrated the reversibility also of these very tight interactions [39] and have enabled determination of $\mathrm{Ki}$ values as low as $\sim 10 \mathrm{fM}$. Recombinant human cystatin $\mathrm{C}$ and two of its mutants were expressed in Escherichia coli. The recombinant inhibitor was found to be identical to authentic cystatin $\mathrm{C}$ as judged by isoelectric focusing (pI 9.2) and kinetics of inhibition of papain and human cathepsins B, H and L. N-terminal truncation of 8 residues resulted in a decrease of isoelectric point (pI 7.8), but the inhibitory properties were similar to those of recombinant cystatin C, suggesting that Leu9 is a critical residue for the inhibition. The mutation of Trp106 to Ser, however, resulted in a decreased affinity of the inhibitor for the enzymes tested, with the largest effect on cathepsin B inhibition (approximately 100-fold increase in Ki) [40]. A review of kinetic and structural data has enabled the authors to reconsider the definition of substrate binding sites in papain-like cysteine proteases. The location and definition of substrate binding sites beyond S3 and S2' are even more questionable [41]. These results clearly indicate differences in the specificity of interaction between the $\mathrm{N}$-terminal region of cystatin C and cathepsins B, H, L and S, and that, although cystatin C has evolved to be a good inhibitor of all of the mammalian cysteine proteinases, more specific inhibitors of the individual enzymes can be engineered [42]. Stopped-flow kinetics showed that the inhibition of the lysosomal cysteine proteinase, cathepsin B, by its endogenous inhibitor, cystatin $\mathrm{C}$, occurs by a two-step mechanism, in which an initial, weak interaction is followed by a conformational change. The initial interaction most likely involves binding of the $\mathrm{N}$-terminal region of the inhibitor to the proteinase. The presence of this loop, which allows the enzyme to function as an exopeptidase, thus complicates the inhibition mechanism, rendering cathepsin B much less susceptible than other cysteine proteinases to inhibition by cystatins [43]. The $\mathrm{N}$-terminal region of human cystatin $\mathrm{C}$ has been shown to be of crucial importance for the interaction of the inhibitor with cysteine proteinases. These results show that bovine cystatin C has 118 residues, in contrast to $110-112$ residues reported previously, and has an $\mathrm{N}$-terminal region analogous to that of human cystatin C (Figure 1). 

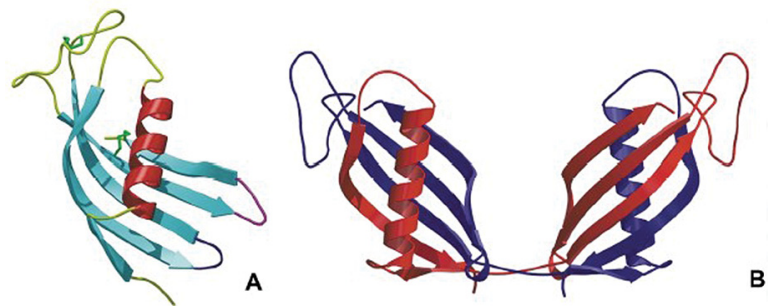

Figure 1. Structure model of cystatin monomer (A) and dimer (B) [44]

On the monomer structure (Fig. 1A) the two disulfide bonds are shown in green, while the long mobile loop connecting strands 3 and 4, positioned upper left, is colored yellow. Blue, lower right, loop 1 shows the hinge region with the swapping domain responsible for the molecule dimerization. The dimer of human cystatin $\mathrm{C}$ structure (Fig. 1B) shows the place where the individual polypeptide chains, colored red and blue, are positioned following the swapping domain. Loop 1 now forms a continuous b-strand linking the two cystatin fold units.

This region presumably is of similar importance for tight binding of target proteinases as human proteases [45] Inhibition of calpain by human kininogen domain 2 requires the correct conformation and combination of several contact sites, and suggest that the $\mathrm{N}$-terminus and the first hairpin loop plays a major role in this ensemble. Remarkably, hybrid sc2-KD2 exhibited 5 or 150 times stronger inhibition of actinidin compared to native chicken cystatin or to proteolytically isolated human kininogen domain 2 , respectively. This indicates an important role of the first hairpin loop of cystatins in the interaction with actinidin. Along with the impaired inhibition of cathepsin L, papain, actinidin, cathepsin $\mathrm{B}$ and calpain by the hybrids sc1/3-KD2, sc2/3-KD2 and $\mathrm{sc} 1 / 2 / 3-\mathrm{KD} 2$, these results support the hypothesis that all three predicted contact regions of kininogen domain 2 contribute to binding in the active-site clefts of papainlike enzymes in a finely balanced manner [46]. The binding of proteinases to kininogen has been the subject of some dispute. Although it has been shown that two of three isolated kininogen domains have an inhibitory activity when studied separately [47], and that the kininogens thus have the potential for binding two molecules of cysteine proteinases, the evidence regarding the binding stoichiometry of the intact molecules was conflicting [48]. Recently, both intact LMK and HMK have been shown by several methods to bind two molecules of papain, cruzipain and cathepsins, H, L and S, thus clarifying the dilemma. Moreover, the two binding sites on HMK and LMK bind proteinase with different binding rates [49]. The three kininogen separates (HMK, LMK and TK) have closely similar inhibitory properties [47], indicating very small differences between their enzyme binding regions. The inhibition of endopeptidases papain, cathepsins $\mathrm{S}$ and $\mathrm{L}$ and cruzipain by animal cystatins are extremely tight and ripped whereas the inhibition of exopeptidases cathepsins $\mathrm{B}$ and $\mathrm{H}$ [50] is considerably weaker. The active site cleft of known endopeptidases is free to accommodate the inhibitors, whereas in the case of exopeptidases the active site cleft contains additional 
enzyme residues. In carboxydipeptidase cathepsin B its occluding loop partly occupies the active site cleft and needs to be displaced in order to accept a cystatin molecule [51]. It was suggested that the mini-chain of aminopeptidase cathepsin $H$, which is attached to the enzyme via a disulphide bridge in the vicinity of the active site, partly fills the active site cleft, therapy offering sterical hindrance to the binding of inhibitors [52].

Most cystatins are reversible, tight binding competitive inhibitors of cysteine proteinases, which form equimolar complexes with their target enzymes [53]. Their general mechanism of action is based on three domains that show highly conserved amino acids sequences. These are important for the inhibitory activity. These domains consist of 10 amino acid residues in the amino terminus, a $\beta$-hairpin loop containing the conserved -QVVAG- residues, and a second $\beta$-hairpin loop containing the conserved residues Leu102, His 104 in family 1 and Trp104 in family 2 cystatins [54]. This wedge penetrates and covers the active site in such a fashion to block the papain or other cysteine proteinase's active site cysteine residue [53,54].

\section{Isolation of cystatins from natural sources}

Cystatin, an inhibitor of sulphydryl proteinases, was the first isolated from egg white by Fossum and Whitaker [55]. Cysteine proteinases are ultimately regulated by endogenous cysteine proteinase inhibitors, also named cystatins [56]. Cystatin superfamily inhibitors have been subdivided into three families, the intracellular type lacking a signal peptide (Type I, cystatin A and B), commonly termed stefins, the abundantly secreted, extracellular inhibitor cystatin C (Type II), and the circulating kininogens (Type III), and non-inhibitory proteins, such as human histidine-rich glycoprotein and 2HS-glycoprotein [57]. The cystatins type II are slightly larger than the stefins and contain 150 amino acid residues with a molecular weight about 13000 . They are non-glycosylated, single chain proteins, having two intermolecular disulphide bridges [12,19]. The family consists mainly of variant species of cystatin $\mathrm{C}$, cystatin $\mathrm{S}$ and its variants, and also cystatin D [58-60]. A novel human cystatin gene was identified in a differential display comparison, aimed at the isolation of transcriptionally regulated genes involved in the invasion and metastasis of breast cancer. It is named cystatin $\mathrm{M}$, with $40 \%$ homology to human family II cystatins and similar overall structure $[61,62]$. Human cystatin $\mathrm{C}$ and its avian analogue chicken cystatin are the most investigated members of the family II. Cystatin $C$ is abundant in various tissues and body fluids. The highest levels have been determined in the cerebrospinal fluid and seminal plasma $[38,63]$. Quail cystatin, a new cysteine proteinase inhibitor of the cystatin superfamily, was purified from egg albumen of the Japanese quail Coturnix corturnix japonica. It showed $90 \%$ sequence identity with chicken cystatin [64]. Two different cysteine proteinase inhibitors (Forms I and II) were isolated from Chum salmon eggs, and their molecular weights were found to be 16000 and 11000 , respectively. They can be classified into the new group of the cystatin superfamily [65]. Also cystatin was isolated from duck egg white. The purified inhibitor that showed partial identity in 
the immunodiffusion test with chicken egg white cystatin had an apparent molecular mass of $9.3 \mathrm{kDa}$ as determined by SDS/PAGE [66,67]. The greatest problem in utilizing egg cystatins for medical treatments is their high cost about 140 \$ USA dollar for $1 \mathrm{mg}$ pure cystatin (catalogue Sigma). Publication on cystatins is less frequent in the literature, probably because of extremely low contents of cystatins in natural resources like eggs [7]. But, on the other hand a few groups are still working in order to find methods of industrial recovering of cystatin from egg white. Six cysteine proteinase inhibitors were isolated from human urine by affinity chromatography on insolubilized carboxymethylpapain followed by ion-exchange chromatography and immunosorption. Physicochemical and immunochemical measurements identified one as cystatin $\mathrm{A}$, one as cystatin $\mathrm{B}$, one as cystatin $\mathrm{C}$, one as cystatin $\mathrm{S}$, and one as low molecular weight kininogen $[68,69]$. The kinetic of papain and cathepsin is described in Table 3 [69].

Table 3. Inhibition constants Ki for chicken egg white [69]

\begin{tabular}{lccc}
\hline \multirow{2}{*}{ Inhibitor } & \multicolumn{3}{c}{ Activity Ki } \\
\cline { 2 - 4 } & $\%$ & Cathepsin B & Papain \\
Chicken egg white age 47 weeks & 75 & 2,554 & 0,0012 \\
Chicken cystatin & 62 & 2,900 & 0,002 \\
\hline
\end{tabular}

$\mathrm{Ki}$ values were determined from the inhibition of the enzymatic activities of papain and cathepsin B measured at equilibrium with the fluorogenic substrate Z-PheArg-AMC for papain and Z-Arg-Arg-AMC for cathepsin B at different inhibitor concentrations. Inhibition of the enzymatic activities of papain and cathepsin $B$ measured at equilibrium with the fluorogenic substrate Z-Phe-Arg-AMC for papain and Z-Arg-Arg-AMC for cathepsin B in different inhibitor concentrations; activity, inhibitory amount expressed as percentage of protein concentration.

\section{CLINICAL RELEVANCE OF CYSTATIN}

\section{Cancer}

The onset/progression of malignant tumor cells is due to an imbalance between cysteine proteinases and their inhibitors [70,71]. However, contradictory data have been shown on cystatin activity in malignant tumors. Cystatin activity has been shown to be higher, similar, or lower compared to the activity found in normal tissues [53]. Others consider that cystatins have an opposite effect in the process of malignancy. They consider that excess of cystatin $C$ could inhibit the proteolytic attack of cathepsins on the cancer cell by suppressing the host inflammatory response and in this way enhancing the oncogenicity of the cell [39]. Cystatin C inhibits motility and in vitro invasiveness of cancer cells, supporting the hypothesis that cystatins play a role in the maintenance of cell differentiation [53,72]. 


\section{Cystatins as disease biomarkers}

Recent studies show that the concentration of cystatins or cystatins and specific cathepsins varies depending on the type of cancer [56]. For example, tissue levels of cystatin $\mathrm{C}$ may be lowered in glioblastoma [73], while it is increased in ovarian cancer [74]. Disturbed balance between cystatins and cysteine proteases is one of the factors characteristic of a malignant tumor cell [71]. Observing the values of individual cystatins and the corresponding cysteine proteases that are expressed in cancer cells can be a valuable tool for assessing and predicting tumor levels and recurrence [56]. In the case of squamous cell carcinoma of the head and neck, it has been proved that specific patterns in the ratio of cystatin and cysteine proteinases are associated with the development of aggressive types of cancer cells and can be used in prognostics [75].

Cystatin $\mathrm{C}$ as an indicator of kidney function has been suggested. Low molecular weight proteins are eliminated from the circulation by glomerular filtration followed by reabsorption and catabolism. In healthy individuals the blood cystatin $C$ level is constant. Serum levels of cystatin $C$ are much more constant than creatinine levels, the best-known marker of glomerular filtration rate. The plasma level of cystatin $\mathrm{C}$ only rises as renal function fails [36,76]. Newman et al [77] reported an assay using cystatin $\mathrm{C}$ that showed to be more sensitive as a screening test for early renal damage than creatinine. Also in veterinary medicine cystatin $\mathrm{C}$ was analyzed as a potential indirect marker for glomerular filtration rate, especially in dogs [78-80]. However, in numerous experiments this proteinase inhibitor was stated as not a good marker for kidney damage [81-86], an early kidney impairment in healthy cats and dogs or dogs with nonrenal diseases should be taken into account. Study of cystatin $\mathrm{C}$ in cats with nonrenal disease is still underestimated, except for hyperthyroidism or with corticosteroid immunosuppressant treatment. The concentration of plasma cystatin $\mathrm{C}$ and especially the urinary cystatin, are more sensitive to detect chronic kidney disease than acute kidney damage in dogs [79,80].

Cystatin $C$ plays a role in Alzheimer's disease by co-deposition with $A \beta$ in the patient's brain binds to APP, $A \beta 1-40$ and $A \beta 1-42$. It also inhibits fibril formation and oligomerization depending on its concentration. In vitro studies indicate that cystatin $C$ protects hippocampal neurons derived from rat brains against toxic oligomers and fibrillary forms of $A \beta[87,88]$. Cystatin $C$ inhibits cysteine proteins, induces autophagy and stimulates neurogenesis [89]. Treatment with egg white cystatin has a beneficial effect on the cognitive functions in APP/PS1 transgenic mice. The strongest effects, measured by swimming ability in the target zone in the Morris water maze, were found in mice drinking water supplied with $40 \mu \mathrm{g}$ of cystatin [90].

\section{Anti-cancer properties of cystatins}

Schelp and Pongpaew [91] suggested that proteinase inhibitors present in cereals like rice and maze can prevent certain types of cancer. Bjornland et al. [92] have reported 
antitumor activity of cysteine proteinase inhibitors, E-64 and leupeptin, by selective reduction of the growth of transformed cells and reduction of the occurrence of cancer in animal models. The authors of Ervin and Cox [93] have shown that Cystatin $\mathrm{C}$ is a factor enhancing apoptosis and limiting the metastasis capacity of neoplastic cells in lung cancer. Other studies conducted on the recombinant cytostatin (sv-cystatin) of the snake show that this cystatin may be an anti-angiogenic and anti-metastatic agent [94]. Other proteolytic enzymes may also play a role in tumor growth. Cathepsin D inactivates cystatins. Inhibitors of cathepsin D may not only prevent tumor growth $[95,96]$, but also prevent the inactivation of cystatins by cathepsin D [97], resulting in an accumulative inhibition of tumor growth $[53,98]$.

\section{Cysteine proteinases in diseases}

Cysteine proteinases activate proinflammatory mediators, and catalyze tissue degradation. Periodontitis and rheumatoid arthritis are inflammatory diseases catalyzed by cysteine proteinases $[53,99]$. Cysteine proteinases have been implicated in cancer malignancy by activating proproteinases like precursors of metalloproteinases [100]. Cysteine proteinases can interfere with chemotherapy due to the inactivation of antitumor drugs such as the case of bleomycin [53]. Smoking is associated with lower cystatin activity during gingival inflammation [101]. Cathepsins B and L are enzymes associated with the onset of rheumatoid arthritis and higher levels of the enzymes are found in synovial tissues and fluids of arthritis patients [102,103]. Therefore, cathepsin B seems to be a good target for pharmacological intervention. Cysteine proteinase inhibitors anti-inflammatory and anti-rheumatic drugs successfully reduce cysteine proteinases that catalyze tissue destruction in rheumatoid arthritis [53].

Human cancer is characterised by its tendency to extend over the peritoneal surface of the abdominal cavity, resulting in a wide-spread disease. At its terminal stages, multiple metastatic foci appear in distant organs, possibly with the involvement of proteolytic enzymes. Cancer cell lines express detectable and reproducible levels of surface urokinase-type plasminogen activator and cathepsin B [104,105]. In primary tumors differ from metastasis in their content of urokinase-type plasminogen activator, its receptor, and the inhibitor type me and II [106]. A latent, high molecular mass form of cathepsin B, presumably pro-cathepsin B, has been shown to accumulate in malignant ascetic fluids, among others from patients with ovarian cancer [107]. Both NTF and scuPA induced a dose-dependent increase in proliferation, with maximal stimulation obtained at 10-20 nM. Furthermore, blocking the interaction of endogenous uPA with uPAR using anti-NTF antibodies significantly inhibited proliferation. Together, these data indicate that in addition to enhancing the invasive activity of ovarian carcinoma cells via increased pericellular proteolysis, uPA also acts as a mitogen for ovarian carcinoma cells, suggesting a biochemical mechanism whereby uPA may contribute to ovarian carcinoma progression by modulating both cell invasion and proliferation [108] Furthermore, in the spontaneous metastasis model, the hybrid protein inhibited the formation of lung and/or lymphatic metastasis by human ovarian carcinoma and 
choriocarcinoma cells. The hybrid protein was much more effective than uPA-(1-134)peptide, UTI-(78-136)-peptide, or UTI. They conclude that this approach extends the possibility of applying recombinant proteins for therapeutic use in inhibition of human tumor cell metastasis [109]. Saleh et al., [110] indicated that egg white cystatin can inhibit the overexpression cathepsins B, L in vitro.

Mice diagnosed with fatal visceral leishmaniasis can be clinically cured by direct implementation of chicken cystatin in synergy with interferon- $\gamma$ (IFN- $\gamma$ ) [111]. Moreover, lethal murine visceral leishmaniasis treated with cystatin $\mathrm{C}$ in combination with IFN- $\gamma$ resulted in cystatin $\mathrm{C}$ and nitric oxide $(\mathrm{NO})$ generation, which at molecular and cellular levels caused Th2 to Th1 conversion reducing parasites and abrogation of parasite infection [112].

\section{Antimicrobial activity}

Alterations to the proteinase inhibitors-cysteine proteinase ratios contribute to the progression of several pathological processes. Cystatins have been shown to play a key role against viruses, bacteria, and parasites, in the control of tumor growth and metastasis, in the protection against tissue destruction, in hereditary cystatin $\mathrm{C}$ amyloid angiopathy, in neurological disorders, and as a marker of glomerular filtration rate $[53,113]$. Many viruses require proteolytic cleavage to become infectious. Cystatins has an activity against a variety of viruses such as poliovirus, rhinovirus, coronavirus, and herpes simplex virus [114-116]. Cystatins have antibacterial properties as well since they play a role in the inhibition of bacterial cysteine proteinases when penetrating normal tissues. Cystatins inhibited the growth of Porphyromonas gingivalis [117-119] and Staphylococcus aureus [120]. Cysteine proteinase inhibitors have also been reported as inhibitors of parasite infections such as malaria [121]. Cystatins also exhibit antifungal activity. Cystatins isolated from chicken eggs showed antifungal activity against pathogenic Candida strains [122]. In some parasitic infections, the parasite obtains free amino acids for protein synthesis via the action of cysteine proteinases, which intracellularly degrade the host proteins. Inhibition of these proteinases correlates with blocking the protein degradation and killing of cultured parasites [53]. A parasitic cysteine proteinase was inhibited by cystatins, namely that of Entamoeba histolytica, which is thought to play an important role in tissue invasion [123]. Cysteine proteinases of cancer cells may facilitate the growth of the tumor due to their ability to degrade stromal tissues and base membranes. Wesierska et al. [124] showed that egg cystatin can be used for its antimicrobial activity (Table 4, and Figure 2). In the Tab. 1 "no" represents lack of inhibition of selected strains by cystatin.

All strains shown in Tab. 4 were isolated from the whole chicken egg and identified by computer analysis (ID 32 GN, ID $32 \mathrm{E}$, and ID 32 STAPH). The strains collection is kept at the Department of Functional Food Products Development, Wroclaw University of Environmental and Life Sciences. 
Table 4. Growth inhibition of some gram positive and negative strains by chicken cystatin with varied concentrations in disk diffusion [109]

\begin{tabular}{|c|c|c|c|c|c|}
\hline \multirow[b]{2}{*}{ Strains } & \multicolumn{5}{|c|}{$\begin{array}{c}\text { Inhibition zones }(\mathrm{mm}) \\
\text { Chicken cystatin }(\mu \mathrm{g} / \mathrm{disk})\end{array}$} \\
\hline & $\begin{array}{c}80 \\
100 \\
120 \\
150 \\
3008080\end{array}$ & 100100 & 120120 & 150150 & 300300 \\
\hline Escherichia coli ATCC 25922 & 11 & 14 & 20 & 21 & \\
\hline Eschericbia coli [01] & 13 & 16 & 21 & 21 & \\
\hline Eschericbia coli [02] & 15 & 19 & 24 & 24 & \\
\hline Pseudomonas aeruginosa ATCC 27853 & $\mathrm{NO}$ & $\mathrm{NO}$ & 16 & 18 & \\
\hline Pseudomonas aeruginosa $\mathrm{F}$ & NO & NO & 16 & 19 & \\
\hline Pseudomonas aeruginosa $\mathrm{P}$ & NO & $\mathrm{NO}$ & 14 & 16 & \\
\hline Staphylococcus gallinarum & 12 & 17 & 23 & 25 & \\
\hline Staphylococcus aureus ATCC 25923 & 12 & 13 & 20 & 20 & \\
\hline Staphylococcus xylosus & NO & NO & 13 & 15 & \\
\hline Serratia liquefaciens & $\mathrm{NO}$ & NO & 13 & 14 & \\
\hline Citrobacter freundii & NO & $\mathrm{NO}$ & NO & NO & NO \\
\hline Acinetobacter lwoffi & 09 & 10 & 16 & 17 & \\
\hline Oligella sp. & 08 & 11 & 17 & 19 & \\
\hline Salmonella enterica Enteritidis [01] & NO & NO & NO & NO & 23 \\
\hline Salmonella enterica Enteritidis [05] & NO & NO & NO & NO & 11 \\
\hline Salmonella enterica Enteritidis [08] & NO & NO & $\mathrm{NO}$ & NO & 12 \\
\hline Salmonella enterica Enteritidis [17] & NO & $\mathrm{NO}$ & $\mathrm{NO}$ & $\mathrm{NO}$ & 17 \\
\hline Salmonella sp. / gr. C [12] & $\mathrm{NO}$ & $\mathrm{NO}$ & $\mathrm{NO}$ & $\mathrm{NO}$ & 16 \\
\hline
\end{tabular}

\section{Potential Food and Pharmaceutical Applications of Cystatins}

Proteinases in the muscles from various fish species cause severe and rapid textural degradation during cooking [125]. Naturally occurring proteinase inhibitors have the ability to prevent fish tissue degradation associated with the proteinases. Successful applications have included the use of beef plasma, whey protein isolates, egg white, potato extract, and lactoalbumin to prevent fish tissue softening [126,127]. Cystatins were reported for eventual use as inhibitors of disintegration of fish, such as minced fish (surimi). Examples are carp ovarian cystatin [128] and chicken cystatin [129]. Those expressed in E. coli in a controlled manner were suitable for industrial use $[128,129]$. The authors report its possible use as inhibitors of surimi gel softening. Also the addition of the recombinant cystatin effectively inhibited the cathepsins activity and affects the degradation of proteins, including myosin, which in consequences improved, soften, the gel properties of mackerel surimi [130,131]. Benjakul et al. [125] and Izquierdo-Pulido et al. [126] have reported applications of rice cystatins versus 


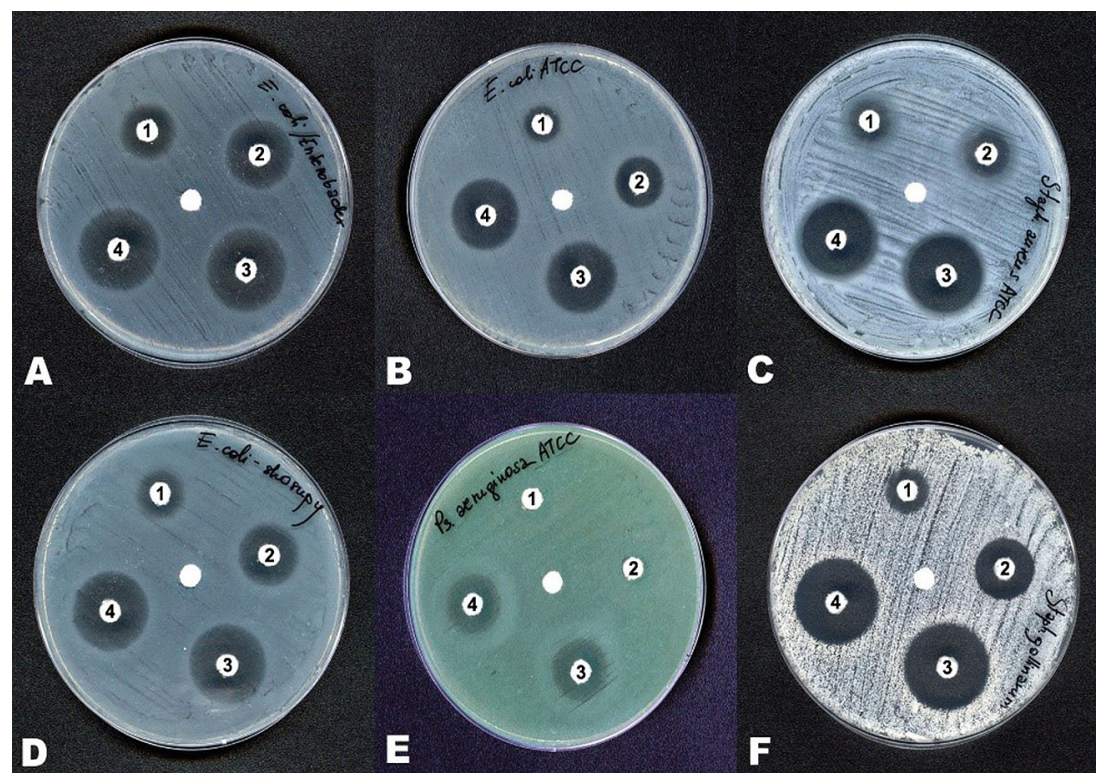

Figure 2. Inhibition zones of six strains of A) Escherichia coli [02], B) Escherichia coli ATCC 25922, C) Staphylococcus aureus ATCC 25923, D) Escherichia coli S, E) Pseudomonas aeruginosa ATCC 27853, F) Staphylococcus gallinarum were spread on Muller-Hinton agar plates on which paper disks impregnated with $80 \mu \mathrm{g}$ (1), $100 \mu \mathrm{g}$ (2), $120 \mu \mathrm{g}$ (3), and $150 \mu \mathrm{g} / \mathrm{disk}$ (4) of chicken cystatin were placed. In the centre of the plate, the disk paper without cystatin added. Incubation period was $24 \mathrm{~h}$ at $37^{\circ} \mathrm{C}[109]$.

proteases in Arrowtooth flounder and Pacific whiting, respectively, the two fish species used in surimi manufacturing. However, the antimicrobial activity of egg white cystatin was very promising for a potential application of this biomolecule in food biopreservation, the duration of the antibacterial effect decreases during long incubation with Escherichia coli [132]. Therefore, cystatin application as a biopreservative of foods is limited.

Cystatins have a potential to be used in food and pharmaceutical formulations as inhibitors of enzymes associated with the onset and/or progression of a wide range of pathological processes. Poliomyelitis caused by poliovirus may be prevented with cystatins. Other pathological processes such as inflammations, infections, osteoporosis, and cancer may also be prevented by cystatins. Cystatins may also find application in the prevention of gingivitis and periodontitis [53].

\section{Authors' contributions}

WK and MK carried out the research planned in the study. PK, WK and MK participated in the alignment and drafted the manuscript. WK and MK participated in the design of the study. PK and MKs participated in its design and coordination and helped to draft the manuscript. All authors read and approved the final manuscript. 


\section{Declaration of conflicting interests}

The author(s) declared no potential conflicts of interest with respect to the research, authorship, and/or publication of this article.

\section{Funding}

The manuscript was co-funded by the Leading Research Groups support project from the subsidy increased for the period 2020-2025 in the amount of $2 \%$ of the subsidy referred to Art. 387 (3) of the Law of 20 July 2018 on Higher Education and Science, obtained in 2019.

\section{REFERENCES}

1. Ochieng J, Chaudhuri G: Cystatin superfamily. J Health care poor underserved 2010, 21:5170.

2. Turk V, Stoka V, Turk D: Cystatins: biochemical and structural properties, and medical relevance. Front Biosci 2008, 13:5406-5420.

3. Turk B, Turk D, Salvesen GS: Regulating cysteine protease activity: essential role of protease inhibitors as guardians and regulators. Curr Pharm Des 2002, 8(18):1623-37.

4. Ni J, Abrahamson M, Zhang M, Fernandez MA, Grubb A, Su J, Yu GL, Li Y, Parmelee D, Xing L, Coleman TA, Gentz S, Thotakura R, Nguyen N, Hesselberg M, Gentz R: Cystatin $\mathrm{E}$ is a novel human cysteine proteinase inhibitor with structural resemblance to family 2 cystatins. J Biol Chem 1997, 272(16):10853-10858.

5. Sánchez A, Vázquez A: Bioactive peptides: A review. Food Qual Saf 2017, 1:29-46.

6. Bouglé D, Bouhallab S: Dietary bioactive peptides: Human studies. Crit Rev Food Sci Nutr 2017, 57(2):335-343.

7. Sim JS, Nakai S, Guenter W: Egg Nutrition and Biotechnology. Wallingford, UK: CAB Int; 2000, 205-217.

8. Neurath H: Evolution of proteolytic enzymes. Sci 1984, 224(4647):350-357.

9. Tavano OL: Protein hydrolysis using proteases: An important tool for food biotechnology. J Mol Catal B Enzym 2013, 90:1-11.

10. Cygler M, Morb JS: Proregion structure of members of the papain superfamily. modeof inhibition of enzymatic activity. Biochem 1997, 79:645-652

11. Matsumoto I, Emori Y, Abe K, Arai S. Characterization of a gene family encoding cysteine proteinases of Sitophilus zeamais (maize weevil), and analysis of the protein distribution in various tissues including alimentary tract and germ cells. J Biochem 1997, 121(3):464-76.

12. Turk V, Bode W: The cystatins: protein inhibitors of cysteine proteinases. FEBS Lett 1991, 285(2):213-219.

13. Jouanin, L, Bonadé-Bottino M, Girard C, Morrot G, Giband M: Transgenic plants for insect resistance. Plant Sci 1998, 131:1-11.

14. Domoney C, Welhan I, Sidebotton C: Purification and characterization of Pisum seed trypsin Inhibitors. J Exp Bot 1993, 44(261):701-709.

15. Zavasnik-Bergant T: Cystatin protease inhibitors and immune functions. Front Biosci 2008, 13:4625-4637. 
16. Colella R, Sakaguchi, Y, Nagase H, Bird JWC: Chicken egg white cystatin. J Biol Chem 1989, 264:17164-17117.

17. Barrett AJ: The Cystatins; a new class of peptidase inhibitors. Trend Biochem Sci 1987, 12:193-196.

18. Arai S, Matsumoto I, Emori Y, Abe K: Plant seed cystatins and their target enzymes of endogenous and exogenous origin. J Agric Food Chem 2002, 50(22): 6612-6617.

19. Benchabane M, Schlüter U, Vorster J, Goulet MC, Michaud D: Plant cystatins. Biochimie 2010, 92(11):1657-1666.

20. Sato, N, Ishidoh K, Uchiyama Y, Kominami E: Molecular cloning and sequencing of cDNA for rat cystatin b. Nucleic Acids Res 1990, 18(22):6698

21. Magister S, Kos, J: Cystatins in immune system. J Cancer 2013, 4(1):45-56.

22. Cornwall GA, Hsia N: A new subgroup of the family 2 cystatins. Mol Cell Endocrinol 2003, 200(1-2):1-8.

23. Amin F, Khan MS, Bano B: Mammalian cystatin and protagonists in brain diseases. J Biomol Struct Dyn 2020, 38(7):2171-2196.

24. Zhou L, Li-Ling J, Huang H, Ma F, Li Q: Phylogenetic analysis of vertebrate kininogen genes. Genomics 2008, 91(2):129-141.

25. Lee C, Bongcam-Rudloff E, Sollner C, Jahnen-Dechent W, Claesson-Welsh L: Type 3 cystatins; fetuins, kininogen and histidine-rich glycoprotein. Front Biosci-Landmrk 2009, 14:2911-2922.

26. Saitoh F, Isemura S, Sanada K, Ohnishi K: Cystatins of family II are harboring two domains which retain inhibitory activities against the proteinase. Biol Biophys Res Commun 1991, 175:1070-1075.

27. Brzin J, Popovic T, Drobnic-Kosorok M, Kotnik M. Turk V: Inhibitors of cysteine proteinases from potato. Biol Chem Hoppe Seyler 1988, 369:233-238.

28. Barrett AJ, Fritz H, Grubb A, Isemura S, Javirnen M, Katunuma N, Machleidt W, MullerEsterl W, Sasaki M, Turk V: Nomenclature and classification of the proteins homologous with the cysteine proteinase inhibitor chicken cystatin. Biochem J 1986, 236:312

29. Turk B, Turk V, Turk D: Structural and functional aspects of papain-like cysteine proteinases and their protein inhibitors. Biol Chem 1997, 378:141-150.

30. Martinez M, Santamaria ME, Diaz-Mendoza M, Arnaiz A, Carrillo L, Ortego F, Diaz I: Phytocystatins: Defense proteins against Phytophagous insects and acari. Int. J Mol Sci 2016, 17(10):1747.

31. Pernas, M.; Sanchez-Monge, R.; Gomez, L. and Salcedo, G: A chestnut seed cystatin differentially effective against cysteine proteinases from closely related pests. Plant Mol Biol 1998, 38(6):1235-1242.

32. Walsh, T. A. and Strickland, J. A: Proteolysis of the 85-kilodalton crystalline cysteine proteinase inhibitor from potato release functional cystatin domains. Plant Physiol 1993, 103(4):1227-1234.

33. Bolter CJ: Methyl jasmonate induces papain inhibitor(s) in tomato leaves. Plant Physiol 1993, 103:1347-135.

34. Abe M, Abe K, Iwabuchi K, Domoto C, Arai S: Corn cystatin I expressed in Escherichia coli: investigation of its inhibitory profile and occurrence in corn kernels. J Biochem 1994, 116 (3):488-492.

35. Zhao Y, Botella MA, Subramanian L, Niu X, Nielson SS, Bressan RA, Hasegawa, PM: Two wound inducible soybean cysteine proteinase inhibitors have greater insect digestive 
proteinase inhibitory activities then a constitutive homolog. Plant Physiol 1996, 111:12991306.

36. Amin F, Khan MS, Bano B:. Mammalian cystatin and protagonists in brain diseases. J Biomol Struct Dyn 2020, 38(7):2171-2196.

37. Vray B, Hartmann S, Hoebeke J: Immunomodulatory properties of cystatins. Cellular and molecular life sciences: CMLS 2002, 59(9):1503-1512

38. Lindahi P, Nycander M, Ylienjaryi K, Pol E, Bjork I: Characterization by rapid-kinetic and equilibrium methods of the reaction between $\mathrm{N}$-terminally truncated forms of chicken cystatin and the cysteine proteinases papain and actinidin. Biochem J 1992, 286:165-171

39. Henskens YMC, Veerman ECJ, Amerongen AVN: Cystatins in health and disease. Biol Chem 1996, 377:71-86.

40. Cimerman N, Prebanda MT, Turk B, Popovic T, Dolenc I, Turk V: Interaction of cystatin C variants with papain and human cathepsins B, H, and L. J. Enz Inhibit 1999, 14:167-174.

41. Turk D, Guncar G, Podobnik M, Turk B: Revised definition of substrate binding sites of papain-like cysteine proteases. Biol Chem 1998, 379:137-147.

42. Mason RW, Sol-Church K, Abrahamson M: Amino acid substitutions in the N-terminal segment of cystatin $\mathrm{C}$ create selective protein inhibitors of lysosomal cysteine proteinases. Biochem J 1998, 330:833-838.

43. Nycander M, Estrada S, Mort JS, Abrahamson M, Bjork I: Two-step mechanism of inhibition of cathepsin B by cystatin $\mathrm{C}$ due to displacement of proteinases occluding loop. FEBS. Lett 1998, 422:61-64.

44. Sanders A, Jeremy Craven C, Higgins LD, Giannini S, Conroy MJ, Hounslow AM, Waltho JP, Staniforth RA: Cystatin forms a tetramer through structural rearrangement of domainswapped dimers prior to amyloidogenesis. J Mol Biol 2004, 336(1):165-78

45. Olsson SL, Ek B, Wilm M, Broberg S, Pask L: Bjork I. Molecular cloning and N-terminal analysis of bovine cystatin C. Identification of full-length N-terminal region. Biochem Biophys. Acta 1997, 1343:203-210.

46. Auerswald EA, Nägler DK, Gross S, Assfalg-Machleidt I, Stubbs MT, Eckerskorn C, Machleidt W, Fritz H. Hybrids of chicken cystatin with human kininogen domain 2 sequences exhibit novel inhibition of calpain, improved inhibition of actinidin and impaired inhibition of papain, cathepsin L and cathepsin B. Eur J Biochem 1996, 235(3):534-42

47. Salvesen G, Parkes C, Abrahamson M, Grubb A, Barrett AJ:. Human low Mr kininogen contains three copies of a cystatin sequence that are divergent in structure and in inhibitory activity for cysteine proteinases. Biochem J 1986, 234:429-434.

48. Sueyoshi T, Hara A, Shimada T, Kimura M, Mortia T, Kato H, Iwanaga S: Molecular interaction of bovine kininogen and its derivatives with papain. J Biochem 1988, 104:200206.

49. Turk B, Stoka V, Turk V, Johansson G, Cazzulo JJ, Bjork I: High-molecular weight kininogen binds two molecules of cysteine proteinases with different rate constants. FEBS Lett 1996, 391:109-112.

50. Bjork I, Pol E, Raub-Segall E, Abrahamson M, Rowan DA, Mort JS: Differential changes in the association and dissociation rate constants for binding of cystatins to target proteinases occurring on $\mathrm{N}$-terminal truncation of the inhibitors indicate that the interaction mechanism varies with different enzymes. Biochem J 1994, 299:219-225.

51. Illy C, Quraishi O, Wang J, Purisima E, Vernet T, Mort JS: Role of the occluding loop in cathepsin activity. J Biol Chem 1997, 272:1197-1202. 
52. Baudys M, Meloun B, Gan-Erdene T, Fusek M, Mares M, Kostka V, Pohl J, Blake CCF: S-S bridges of cathepsin B and H from bovine spleen: A basis for cathepsin B model building and resulting possible functional implications for determination between exo- and endopeptiase activities among cathepsins B, H, and L. Biomed. Biochim Acta 1991, 50:569577.

53. Blankenvoorde MFJ, Brand HS, Henskens YMC, Veerman ECI, Nieuw Amerongen AV: Protease inhibitors in health and disease control - Medical and industrial aspects. In: Recombinant protease inhibitors in plants. Georgetown, Texas, USA: Landes Biosci 2000, 203-214.

54. Calkins CC, Sloane BF: Mammalian cysteine protease inhibitors: biochemical properties and possible roles in tumor progression. Biol Chem Hoppe Seyler 1995, 376(2):71-80.

55. Fossum, K, Whitaker JR: Ficin and papain inhibitor from chicken egg white. Arch Biochem Biophys 1968, 125:367-375.

56. Breznik B, Mitrović A, T Lah T, Kos J: Cystatins in cancer progression: More than just cathepsin inhibitors. Biochimie 2019, 166:233-250.

57. Rawling ND, Barrett AJ: Evolution of proteins of the cystatin superfamily. Biochem Biophys Res Commun 1990, 118:103-109.

58. Bezin J, Popovie T, Turk V, Brochart U, Machleidt W: Human cystatin a new protein inhibitor of cysteine proteinases. Biochem Biophys Res Commun 1984, 118:103-109.

59. Freije JP, Abrahamson M, Olafsson I, Velasco G, Grubb A, Lopez-Otin C: Structure and expression of the gene encoding cystatin $\mathrm{D}$, a novel human cysteine proteinase inhibitor. J Biol Chem 1991, 266:20538-20543.

60. Werle B, Sauckel K, Nathanson CM, Bjarnadottir M, Spiess E, Ebert W, Abrahamson $\mathrm{M}$ : Cystatins $\mathrm{C}, \mathrm{E} / \mathrm{M}$ and $\mathrm{F}$ in human pleural fluids of patients with neoplastic and inflammatory lung disorders. Biol Chem 2003, 384(2): 281-287.

61. Sotiropoulou G, Anisowicz A, Sager R: Identification, cloning, and characterization of cystatin M, a novel cysteine proteinase inhibitor, down-regulated in breast cancer. J. Biol Chem 1997, 272:903-910.

62. Cheng T, Hitomi K, van Vlijmen-Willems IM, de Jongh GJ, Yamamoto K, Nishi K, Watts C, Reinheckel T, Schalkwijk J, Zeeuwen PL: Cystatin M/E is a high affinity inhibitor of cathepsin $\mathrm{V}$ and cathepsin $\mathrm{L}$ by a reactive site that is distinct from the legumain-binding site. A novel clue for the role of cystatin $\mathrm{M} / \mathrm{E}$ in epidermal cornification. J Biol Chem 2006, 281(23):15893-15899.

63. Prunk M, Perišić Nanut M, Sabotič J, Kos J. Cystatins, cysteine peptidase inhibitors, as regulators of immune cell cytotoxicity. Period Biol 2016, 118(4):353-362.

64. Gerhartz B, Engh RA, Menttele R, Eckerskom C, Torquato R, Wittmann J, Kolb HJ, Macheidt W, Fritz H, Auerswald EA: Quail cystatin: Isolation and charactrization of a new member of the cystatin family and its hypothetical interaction with cathepsin B. FEBS Lett 1997, 412:551-558.

65. Mashita M., Konagaya S: Cysteine proteinase inhibitor in egg of Chum salmon. J Biochem 1991, 110(5):762-766.

66. Warwas M, Gburek J, Osada J, Garab K: Purification and characterization of cystatin from duck egg white. Acta Biochim Pol 1995, 42:351-356.

67. Naknukool S, Hayakawa S, Sun Y, Ogawa M: Structural and physicochemical characteristics of novel basic proteins isolated from duck egg white. Biosci Biotech Bioch 2008, 72(8):2082-2091. 
68. Abrahamson M, Barrett AJ, Salvesen G, Grubb A: Isolation of six cysteine proteinase inhibitors from human urine. J Biol Chem 1986, 261:11282-11289

69. Trziszka T, Saleh Y, Kopeć W, Siewiński M, Wesierska E: Effect of hen's age on the level of cystatin in chicken egg white. Int J Poul Sci 2004, 3:1-8.

70. Calkins CC, Sloane BF: Mammalian cysteine protease inhibitors: biochemical properties and possible roles in tumor progression. Biol Chem Hoppe Seyler 1995, 376(2):71-80.

71. Høyer-Hansen G, Blasi F, Sloane B.F: Cysteine cathepsins and cystatins as cancer biomarkers. In: Edwards D., (eds) The Cancer Degradome 2008, Springer, New York.

72. Leto G, Crescimanno M Flandina C: On the role of cystatin C in cancer progression. Life Sci 2018, 202:152-160.

73. Nakabayashi H, Hara M, Shimuzu K: Clinicopathologic significance of cystatin C expression in gliomas. Hum Pathol 2005, 36(9):1008-1015.

74. Nishikawa H, Ozaki Y, Nakanishi T, Blomgren K, Tada T, Arakawa A, Suzumori K: The role of cathepsin $\mathrm{B}$ and cystatin $\mathrm{C}$ in the mechanisms of invasion by ovarian cancer. Gynecol Oncol 2004, 92(3):881-886.

75. Strojan P, Aničin A, Svetic B, Šmid L, Kos J:. Proteolytic profile of cysteine proteases and inhibitors determines tumor cell phenotype in squamous cell carcinoma of the head and neck. Int. J Biol Markers 2011, 26(4):247-254.

76. Ferguson TW, Komenda P, Tangri N: Cystatin C as a biomarker for estimating glomerular filtration rate. Curr Opin Nephrol Hypertens 2015, 24(3):295-300.

77. Newman DJ, Thakkar H, Edwards RG, Wilkie M, White T, Grubb AO, Price CP: Serum cystatin $\mathrm{C}$ measured by automated immunoassay: a more sensitive marker of changes in GFR than serum creatinine. Kidney Int 1995, 47(1):312-318.

78. Kim J, Lee CM, Kim HJ: Biomarkers for chronic kidney disease in dogs: a comparison study. J Vet Med Sci 2020, 82(8):1130-1137.

79. Ghys L, Paepe D, Smets P, Lefebvre H, Delanghe J, Daminet S: Cystatin C: a new renal marker and its potential use in small animal medicine. J Vet Intern Med 2014, 28(4):11521164.

80. Kovarikova S: Indirect markers of glomerular filtration rate in dogs and cats: a review. Vet Med 2018, 63:395-412.

81. Miyagawa Y, Takemura N, Hirose H: Evaluation of the measurement of serum cystatin $\mathrm{C}$ by an enzyme-linked immunosorbent assay for humans as a marker of the glomerular filtration rate in dogs. J Vet Med Sci 2009, 71:1169-1176.

82. Antognoni MT, Siepi D, Porciello F, Rueca F, Fruganti G: Serum cystatin-C evaluation in dogs affected by different diseases associated or not with renal insufficiency. Vet Res Commun 2007, 31(Suppl 1):269-271.

83. Martin C, Péchereau D, De la Farge F, Braun JP: Cystatine C plasmatique chez le chat: Les technique actuelles ne permettent pas de l'utiliser comme marqueur d'insufficance rénale. Rev Med Vet 2002, 153:305-310.

84. Poswiatowska-Kaszczyszyn I. Usefulness of serum cystatin C measurement for assessing renal function in cats. Bull Vet Inst Pulawy 2012, 56:235-239.

85. Ghys LF, Paepe D, Lefebvre HP, Reynolds BS, Croubels S, Meyer E, Delanghe JR, Daminet $\mathrm{S}$ : Evaluation of cystatin $\mathrm{C}$ for the detection of chronic kidney disease in cats. J Vet Intern Med 2016, 30(4):1074-82. 
86. Ghys LFE, Paepe D, Taffin ERL, Vandermeulen E, Duchateau L, Smets PMY, Delanghe J, Daminet S: Serum and urinary cystatin $C$ in cats with feline immunodeficiency virus infection and cats with hyperthyroidism. J Feline Med Surg 2016, 18(8):658-65.

87. Tizon B, Ribe EM, Mi W, Troy CM, Levy E: Cystatin C protects neuronal cells from amyloid-beta-induced toxicity. J Alzheimers Dis 2010, 19:885-894.

88. Mi W, Pawlik M, Sastre M, Jung SS, Radvinsky DS, Klein AM, Sommer J, Schmidt SD, Nixon RA, Mathews PM, Levy E: Cystatin C inhibits amyloid-beta deposition in Alzheimer's disease mouse models. Nat Genet 2007, 39(12):1440-1442.

89. Gauthier S, Kaur G, Mi W, Tizon B, Levy E: Protective mechanisms by cystatin C in neurodegenerative diseases. Front Biosci 2011, 3:541-554.

90. Stańczykiewicz B, Jakubik-Witkowska M, Rutkowska M, Polanowski A, Gburek J, Gołąb K, Juszczyńska K, Trziszka T, Rymaszewska J: Beneficial effect of ovocystatin on the cognitive decline in APP/PS1 transgenic mice. Adv Med Sci 2019, 64(1):65-71.

91. Schelp FP, Pongpaew P: Protection against cancer through nutritionally-induced increase of endogenous proteinase inhibitors - a hypothesis. Int J Epidemiol 1988, 17(2):287-92.

92. Bjornland K, Buo L, Kjonniksen I, Larsen M, Fodstad O, Johansen HT, Aasen AO: Cysteine proteinase inhibitors reduce malignant melanoma cell invasion in vitro. Anticancer Res 1996, 16(4A):1627-1631.

93. Ervin H, Cox JL: Late stage inhibition of hematogenous melanoma metastasis by cystatin C over-expression. Cancer Cell Int 2005, 5(1):14.

94. Xie Q, Tang N, Lin Y, Wang X, Lin X, Lin J: Recombinant adenovirus snake venom cystatin inhibits the growth, invasion, and metastasis of B16F10 cells in vitro and in vivo. Melanoma Res 2013, 23(6):444-51.

95. Ren WP, Sloane BF: Cathepsins D and B in breast cancer. Cancer Treat Res 1996, 83:32552.

96. Laurent-Matha V, Huesgen PF, Masson O, Derocq D, Prébois C, Gary-Bobo M, Lecaille F, Rebière B, Meurice G, Oréar C, Hollingsworth RE, Abrahamson M, Lalmanach G, Overall CM, Liaudet-Coopman E: Proteolysis of cystatin C by cathepsin D in the breast cancer microenvironment. FASEB J 2012, 26(12):5172-81.

97. Lenarcic B, Kos J, Dolenc I, Lucovnik P, Krizaj I, Turk V. Cathepsin D inactivates cysteine proteinase inhibitors, cystatins. Biochem Biophys Res Commun 1988, 154(2):765-72.

98. Tokyol C, Köken T, Demirbas M, Dilek FH, Yörükoglu K, Mungan U, Kirkali Z: Expression of cathepsin D in bladder carcinoma: correlation with pathological features and serum cystatin C levels. Tumori 2006, 92(3):230-235.

99. Aghdassi AA, John DS, Sendler M, Weiss FU, Reinheckel T, Mayerle J, Lerch MM: Cathepsin $\mathrm{D}$ regulates cathepsin $\mathrm{B}$ activation and disease severity predominantly in inflammatory cells during experimental pancreatitis. J Biol Chem 2018, 293(3):1018-1029.

100. Berquin IM, Sloane BF: Cathepsin B expression in human tumors. Adv Exp Med Biol 1996, 389:281-294

101.Lie MA, Loos BG, Henskens YM, Timmerman MF, Veerman EC, van der Velden U, van der Weijden GA. Salivary cystatin activity and cystatin $C$ in natural and experimental gingivitis in smokers and non-smokers. J Clin Periodontol 2001, 28(10):979-984

102. Buttle DJ, Bramwell H, Hollander AP: Proteolytic mechanisms of cartilage breakdown: A target for arthritis therapy? J Clin Pathol 1995, 48:167-177.

103. Požgan U, Caglič D, Rozman B, Nagase H, Turk V, Turk B: Expression and activity profiling of selected cysteine cathepsins and matrix metalloproteinases in synovial fluids 
from patients with rheumatoid arthritis and osteoarthritis, Biological Chemistry 2010, 391(5):571-579.

104. Kobayashi H, Ohi H, Sugimura M, Shinohara H, Fujii T, Terao T: Inhibition of in vitro ovarian cancer cell invasion by modulation of urokinase-type plasminogen activator and cathepsin B. Cancer Res 1992, 52:3610-3614.

105.Levicar N, Kos J, Blejec A, Golouh R, Vrhovec I, Frkovic-Grazio S, Lah TT: Comparison of potential biological markers cathepsin B, cathepsin L, stefin A and stefin B with urokinase and plasminogen activator inhibitor-1 and clinicopathological data of breast carcinoma patients. Cancer Epidemiol 2002, 26(1):42-49.

106. Schmalfeldt B, Kuhn W, Reuning U, Pache L, Dettmar P, Schmitt M, Janicke F, Hofler $\mathrm{H}$, Graeff $\mathrm{H}$ : Primary tumor and metastasis in ovarian cancer differ in their content of urokinase-type plasminogen activator, and inhibitors types 1 and 2. Cancer Res 1995, 55:3958-3963.

107. Keppler D, Abrahamson M, Sordat B: Secretion of cathepsin B and tumour invasion. Biochem Soc Trans 1994, 22:43-49.

108. Kobayashi H, Sugino D, She MY, Ohi H, Hirashima Y, Shinohara H, Fujie M, Shibata K, Terao T: A bifunctional hybrid molecule of the amino-terminal fragment of urokinase and domain II of bikunin efficiently inhibits tumor cell invasion and metastasis. Eur J Biochem 1998, 1;253(3):817-826.

109. Thomssen C, Oppelt P, Janicke F, Ulm K, Harheck N, Hofler H, Kuhn W, Graeff H, Schmitt M: Identification of low-risk node-negative breast cancer patients by tumors biological factors PAI-I and cathepsin L. Anticancer Res 1998. 18, 2173 - 2180.

110. Saleh Y, Siewinski M, Kielan W, Ziolkowski P: Activities of cysteine proteinases cathepsin $\mathrm{B}, \mathrm{L}$ and their inhibitors: regulation of cathepsin $\mathrm{B}$ and $\mathrm{L}$ expression by egg white cysteine proteinase inhibitor. J Exp Ther Oncol 2003, 3:319-324.

111. Verdot L, Lalmanach G, Vercruysse V, Hartmann S, Lucius R, Hoebeke J, Gauthier F, Vray B: Cystatins up-regulate nitric oxide release from interferon-gamma-activated mouse peritoneal macrophages. J Biol Chem 1996, 271(45):28077-28081.

112.Das L, Datta N, Bandyopadhyay S, Das PK: Successful therapy of lethal murine visceral leishmaniasis with cystatin involves up-regulation of nitric oxide and a favorable $\mathrm{T}$ cell response. J Immunol 2001, 166(6):4020-4028.

113. Henskens YM, Veerman EC, Nieuw Amerongen AV.. Cystatins in health and disease. Biol Chem Hoppe Seyler 1996, 377(2):71-86

114. Aoki H, Akaike T, Abe K, Kuroda M, Arai S, Okamura R Neji A, Maeda H: Antiviral effect of oryzacystatin, a proteinase inhibitor in rice, against herpes simplex virus type 1 in vitro and in vivo. Antimicrob Agent Chemother 1995, 39:846-849.

115. Kondo H, Ijiri S, Abe K, Maeda H, Arai S: Inhibitory effect of oryzacystatins and a truncation mutant of the replication of poliovirus in infected Vero cells. FEBS Lett 1992, 299:48-50.

116. Kan Y, Okabayashi T, Yokota S, Yamamoto S, Fujii N, Yamashita T: Imiquimod suppresses propagation of herpes simplex virus 1 by upregulation of cystatin A via the adenosine receptor A1 pathway. J Virol 2012, 86(19):10338-10346.

117. Blankenvoorde MFJ, Henskens YMC, Van't Hof W: Antibacterial activity against Porphyromonas gingivalis by cystatins. In: Hopsu Havu VK, Jarvinen M, Kirschke H, eds. Proteolysis in cell fuctions. Amsterdam: IOS Press. 1997, 532-539.

118. Naito Y, Sasaki M, Umemoto T: Bacterial effect of rat cystatin S on an oral bacterium, Porphyromonas gingivalis. Comp Biochem Physiol 1995, 110:71-75. 
119. Grenier D: Effect of protease inhibitors on in vitro growth of Porphyromonas gingivalis. Microb Ecol Health Dis 1992, 5:133-138.

120. Takahashi M, Tezuka T, Katunuma N: Inhibition of growth and cysteine proteinase activity of Staphylococcus aureus V8 by phosphorylated cystatin A in skin cornified envelope. FEBS Lett 1994, 355:275-278.

121. Melo P, El Chamy Maluf S, Azevedo MF, Paschoalin T, Budu A, Bagnaresi P, HenriqueSilva F, Soares-Costa A, Gazarini ML, Carmona AK: Inhibition of Plasmodium falciparum cysteine proteases by the sugarcane cystatin CaneCPI-4. Parasitol Int 2018, 67(2):233-236.

122. Kolaczkowska A, Kolaczkowski M, Sokolowska A, Miecznikowska H, Kubiak A, Rolka $\mathrm{K}$, Polanowski A: The antifungal properties of chicken egg cystatin against Candida yeast isolates showing different levels of azole resistance. Mycoses 2010, 53(4):314-320.

123.Luaces AL, Barrett AJ: Affinity purification and biochemical characterization of histolysin, the major cysteine proteinase of Entamoeba histolytica. Biochem J 1998, 250(3):903-909.

124. Wesierska, E, Saleh, Y, Trziszka, T, Kopeć W, Siewiński M, Korzekwa K. Antimicrobial activity of chicken egg white cystatin. World J Microbiol Biotechnol 2005, 21:59-64.

125.Benjakul S, Visessanguan W, An H.. Properties of cysteine proteinase inhibitors from black gram and rice bean. J Food Chem 2001, 25:211-227.

126.Izquierdo-Pulido ML, Haard TA, Hung J, Haard NF: Oryzacystatin and other proteinase inhibitors in rice grain: potential use as a fish processing aid. J Agric Food Chem 1994, 42:616-622.

127. Singh A, Benjakul S: Proteolysis and Its Control Using Protease Inhibitors in Fish and Fish Products: A Review. Compr. Rev. Food Sci. Food Saf 2018, 17:496-509.

128. Tzeng SS, Chen GH, Chung YC, Jiang ST: Expression of soluble form carp (Cyprinus carpio) ovarian cystatin in Escherichia coli and its purification. J Agric Food Chem 2001, 49:4224-4230.

129.Jiang ST, Tzeng SS, Wu WT, Chen GH: Enhanced expression of chicken cystatin as a thioredoxin fusion form in Escherichia coli AD494(DE3)pLysS and its effect on the prevention of surimi gel softening. J Agric food Chem 2002, 50:3731-3737.

130.Jiang ST, Hsieh JF, Tsai GJ: Interactive effects of microbial transglutaminase and recombinant cystatin on the mackerel and hairtail muscle protein. J Agric Food Chem 2004, 52(11):3617-3625.

131.Chen GH, Tang SJ, Chen CS, Jiang ST: High-level production of recombinant chicken cystatin by Pichiapastoris and its application in mackerel surimi. J Agric Food Chem 2001, 49(2):641-646.

132.Szpak M, Trziszka T, Polanowski A, Gburek J, Gołąb K, Juszczyńska K, Janik P, Malicki A, Szyplik K: Evaluation of the antibacterial activity of cystatin against selected strains of Escherichia coli. Folia Biologica (Kraków), 2014, 62:187-192. 


\section{CISTATIN BELANCA JAJA - PREGLED}

KUPAJ Patryk, KORUS Maciej, KORZENIOWSKA Malgorzata, KOPEC Wieslaw

Belance jajeta je u širokoj upotrebi i to ne samo za ishranu ljudi već i kao sirovina za prehrambenu industriju, farmaceutsku i kozmetičarsku industriju. Cistatin je biološki aktivna komponenta belanca jaja i većinom se koristi kao inhibitor cistein proteaza nalik na papain. Cistatin je izolovan iz kokošjh jaja i kasnije upotrebljen za formiranje nomenklature strukturno i funkcionalno sličnih proteina. Cistatini poreklom od životinja, uključujući i miševe, pacove, pse, goveda i iz belanaca kokošjh jaja, izolovani su i nedavno su upotrebljeni za ishranu ljudi i za farmaceutsku industriju. Cistatin na našao svoju upotrebu i upotrebu u medicini zahvaljujući antibakterijskim, antivirusnim $\mathrm{i}$ insekticidnim efektima $\mathrm{i}$ to u cilju prevencije cerebralnih hemoragija $\mathrm{i}$ za kontrolu metastaza kod tumora. 